\title{
Labyrinthe
}

23 | 2006 (1)

Quatre chercheurs de l'étranger

\section{Dans les interstices de la mosaïque}

cultures et identités des exilés du nazisme au Canada

\section{Patrick Farges}

\section{CpenEdition}

Journals

Édition électronique

URL : http://journals.openedition.org/labyrinthe/1166

DOI : $10.4000 /$ labyrinthe. 1166

ISSN : 1950-6031

Éditeur

Hermann

Édition imprimée

Date de publication : 15 janvier 2006

ISBN : 2-9526131-0-9

Référence électronique

Patrick Farges, "Dans les interstices de la mosaïque », Labyrinthe [En ligne], 23 | 2006 (1), mis en ligne le 09 mars 2006, consulté le 26 avril 2019. URL : http://journals.openedition.org/labyrinthe/1166 ; DOI : 10.4000/labyrinthe.1166

Ce document a été généré automatiquement le 26 avril 2019

Propriété intellectuelle 


\title{
Dans les interstices de la mosaïque
}

Cultures et identités des exilés du nazisme au Canada

\author{
Patrick Farges
}

